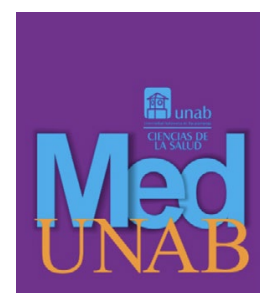

REVISTA DE LA FACULTAD

DE CIENCIAS DE LA SALUD

\title{
Familial hypocalciuric hypercalcemia as a differential diagnosis of primary hyperparathyroidism with negative images
}

Hipercalcemia hipocalciúrica familiar como diagnóstico diferencial de hiperparatiroidismo primario con imágenes negativas

Hipercalcemia hipocalciúrica familiar como diagnóstico diferencial de hiperparatireoidismo primário com imagens negativas

Edwin Antonio Wandurraga-Sánchez, MD., Sp. ${ }^{1}$ (D, Mario Alejandro BuitragoGómez, MD. ${ }^{2}$ (D), María Camila Uribe-Forero, MD. ${ }^{2}$ (D), Néstor Andrés Díaz-Posada, MD., Sp. ${ }^{3}$ (D), María Camila Amaya-Muñoz, St. ${ }^{4}$ (D)

1. Physician, Specialist in Internal Medicine and Endocrinology, Associate Professor. Fundación Oftalmológica de Santander, Universidad Autónoma de Bucaramanga. Bucaramanga, Santander, Colombia.

2. Physician, Epidemiology Specialization Student. Universidad Autónoma de Bucaramanga. Bucaramanga, Santander, Colombia.

3. Physician, Specialist in Epidemiology, Internal Medicine Resident. Universidad Autónoma de Bucaramanga. Bucaramanga, Santander, Colombia.

4. Medical Student. Universidad Autónoma de Bucaramanga. Bucaramanga, Santander, Colombia.

Correspondence. Edwin Antonio Wandurraga Sánchez. Centro Médico Carlos Ardila Lulle, Torre B, Piso 8, Módulo 55, Consultorio 806. Floridablanca, Santander, Colombia. Email. edwinwandurraga@gmail.com

\section{ARTICLE INFORMATION:}

Article received: January 12, 2021

Article accepted: October 21, 2021

DOI: https://doi.org/10.29375/01237047.4072

How to cite. Wandurraga-Sánchez EA, Buitrago-Gómez MA, UribeForero MC, Díaz-Posada NA, Amaya-Muñoz MC. Familial hypocalciuric hypercalcemia as a differential diagnosis with negative images for primary hyperparathyroidism. MedUNAB [Internet]. 2021;24(3):347-352. doi: https:// doi.org/10.29375/01237047.4072

\section{ABSTRACT:}

Introduction. Familial hypocalciuric hypercalcemia is a rare inherited calcium metabolism disorder in which an alteration of the parathyroid hormone secretion set-point causes hypercalcemia with relative hypocalciuria. Some data suggest that 
its prevalence is around 74.1 per 100,000 inhabitants. Often, patients are asymptomatic. However, they can develop mild symptoms and an overactive parathyroid adenoma, its main differential diagnosis. The objective was to describe a patient's case and highlight the importance of clinical suspicion and diagnosis to avoid unnecessary surgical neck explorations for parathyroid adenomas. Case report. This is the case of a 40-year-old man with a biochemical profile compatible with primary hyperparathyroidism with anatomical and functional images negative for adenoma and a calcium/creatinine clearance ratio below 0.001, considering familial hypocalciuric hypercalcemia. Genetic studies evidence a mutation in the calcium sensor receptor gene and confirm the diagnosis. Discussion. Familial hypocalciuric hypercalcemia's main differential diagnosis is an overactive parathyroid adenoma. For both, mild or no symptoms may be present; serum calcium exceeds the upper limit, and parathormone is more than $25 \mathrm{pg} / \mathrm{ml}$. The calcium $/$ creatinine clearance ratio should be used to differentiate one from the other and avoid unnecessary surgical neck explorations. Besides the lack of information on this topic, evidence supports the use of calcimimetics to treat symptomatic hypercalcemia. Conclusions. Patients with mild hypercalcemia with parathyroid hormone readings above $25 \mathrm{pg} / \mathrm{ml}$ and a calcium/creatinine clearance ratio below 0.001 , or patients with primary hyperparathyroidism with negative imaging, should not undergo surgical neck explorations. In these cases, familial hypocalciuric hypercalcemia is a reliable diagnosis; Cinacalcet may be administered in cases of symptomatic hypercalcemia.

Keywords:

Hypercalcemia; Hyperparathyroidism, Primary; Cinacalcet; Case Reports; Genetics.

\section{RESUMEN}

Introducción. La hipercalcemia hipocalciúrica familiar es un trastorno hereditario poco común del metabolismo del calcio en donde una alteración del punto de ajuste de la secreción de hormona paratiroidea ocasiona hipercalcemia con hipocalciuria relativa. Algunos datos sugieren que su prevalencia es de alrededor de 74.1 por 100,000 habitantes. Los pacientes muchas veces son asintomáticos. Sin embargo, pueden desarrollar síntomas leves y un adenoma paratiroideo hiperactivo, que representa su principal diagnóstico diferencial. El objetivo fue describir el caso de un paciente y resaltar la importancia de la sospecha y el diagnóstico clínicos para evitar exploraciones quirúrgicas cervicales innecesarias en búsqueda de adenomas paratiroideos. Reporte de caso. Este es el caso de un hombre de 40 años con un perfil bioquímico compatible con hiperparatiroidismo primario, con imágenes anatómicas y funcionales negativas para adenoma, además de una relación de depuración de calcio/creatinina menor a 0.001 , con consideración de hipercalcemia hipocalciúrica familiar. Los estudios genéticos evidencian una mutación en el gen del receptor sensor del calcio y confirman el diagnóstico. Discusión. El principal diagnóstico diferencial de la hipercalcemia hipocalciúrica familiar es un adenoma paratiroideo hiperactivo. En ambos casos, es posible que no haya síntomas o que estos sean leves; el calcio sérico excede al límite superior, y la paratohormona es mayor de $25 \mathrm{pg} / \mathrm{ml}$. Se debe usar la relación de depuración de calcio/creatinina para diferenciar entre estas patologías y evitar exploraciones quirúrgicas cervicales innecesarias. Aparte de la falta de información sobre este tema, la evidencia apoya el uso de calciomiméticos para tratar la hipercalcemia sintomática. Conclusiones. Los pacientes con hipercalcemia leve, con valores de hormona paratiroidea mayores de $25 \mathrm{pg} / \mathrm{ml}$ y con una relación de depuración de calcio/creatinina menor de 0.001, o los pacientes con hiperparatiroidismo primario con imágenes negativas, no deben ser sometidos a exploraciones quirúrgicas cervicales. En estos casos, la hipercalcemia hipocalciúrica familiar representa un diagnóstico confiable; se puede administrar Cinacalcet en casos de hipercalcemia sintomática.

Palabras clave:

Hipercalcemia; Hiperparatiroidismo primario; Cinacalcet; Informes de Casos; Genética.

\section{RESUMO}

Introdução. A hipercalcemia hipocalciúrica familiar é um distúrbio hereditário raro do metabolismo do cálcio, no qual uma alteração no ponto de ajuste da secreção do hormônio da paratireóide causa 
hipercalcemia com hipocalciúria relativa. Alguns dados sugerem que sua prevalência gira em torno de 74.1 por 100,000 habitantes. Os pacientes geralmente são assintomáticos. No entanto, eles podem desenvolver sintomas leves e um adenoma de paratireoide hiperativo, que representa seu principal diagnóstico diferencial. O objetivo foi descrever o caso de um paciente e destacar a importância da suspeita clínica e do diagnóstico para evitar exploração cirúrgica cervical desnecessária em busca de adenomas de paratireoide. Relato de caso. É o caso de um homem de 40 anos com perfil bioquímico compatível com hiperparatireoidismo primário, com imagens anatômicas e funcionais negativas para adenoma, além de relação depuração de cálcio/creatinina menor que 0.001 , considerando hipercalcemia hipocalciúrica familiar. Estudos genéticos revelam uma mutação no gene receptor da sensibilidade ao cálcio e confirmam o diagnóstico. Discussão. O principal diagnóstico diferencial da hipercalcemia hipocalciúrica familiar é um adenoma de paratireoide hiperativo. Em ambos os casos, os sintomas podem estar ausentes ou leves; o cálcio sérico excede o limite superior e o hormônio da paratireóide é superior a $25 \mathrm{pg} / \mathrm{ml}$. A relação depuração de cálcio/creatinina deve ser usada para diferenciar entre essas patologias e evitar exploração cirúrgica cervical desnecessária. Além da falta de informações sobre esta questão, as evidências apoiam o uso de calcimiméticos para tratar a hipercalcemia sintomática. Conclusões. Pacientes com hipercalcemia leve, com valores de hormônio da paratireóide maiores que $25 \mathrm{pg} / \mathrm{ml}$ e uma relação de depuração de cálcio/creatinina menor que 0.001, ou pacientes com hiperparatireoidismo primário com imagens negativas, não devem ser submetidos a exploração cirúrgica cervical. Nesses casos, a hipercalcemia hipocalciúrica familiar representa um diagnóstico confiável; Cinacalcet pode ser administrado em casos de hipercalcemia sintomática.

Palavras-chave:

Hipercalcemia; Hiperparatireoidismo Primário; Cinacalcete; Relato de Casos; Genética.

\section{Introduction}

Familial hypocalciuric hypercalcemia (FHH), formerly called benign familial hypercalcemia, is an inherited autosomal dominant disorder caused by mutations in the gene expressing the calcium-sensing receptor (CaSR) in the parathyroid glands, kidneys, and other organs. Mutations leading to partial or complete loss of CaSR function cause a shift in the parathyroid cells' set-point for calcium. Consequently, a higher-than-normal blood calcium concentration is needed to inhibit parathormone (PTH) secretion. In addition, the abnormal function of CaSR in the ascending branch of Henle's loop results in $\mathrm{PTH}$-independent calcium reabsorption and consequent hypocalciuria $(1,2)$.

Its main differential diagnosis is primary hyperparathyroidism due to an overactive parathyroid adenoma, presenting a broad spectrum of clinical manifestations. Not unlike FHH, in mild cases, primary hyperparathyroidism presents no symptoms. However, the symptoms may include polyuria, polydipsia, or acute pancreatitis when present. This relatively frequent endocrine disease has an estimated prevalence of $0.8 \%$ in the adult population. In contrast, $\mathrm{FHH}$ is an uncommon and often underdiagnosed disease, with some data suggesting its prevalence is around 74.1 per 100,000 inhabitants. In most cases, no treatment is required (3-6).
There is no data on this disease's frequency in our population. Therefore, our objective was to describe the case of a patient and highlight the importance of clinical suspicion and diagnosis to avoid unnecessary surgical neck explorations for parathyroid adenomas.

\section{Case presentation}

The subject was a 40-year-old male New Zealander living in Colombia for six years; he consulted for having polyuria (>3.5 liters per day) and polydipsia associated with migraine-type headaches for 18 months. His medical history included bilateral knee surgery for chondrocalcinosis; however, no other medical conditions were reported.
Despite being within reference values, mild hypercalcemia with unsuppressed PTH was documented in laboratories. In addition, other causes of osmotic polyuria and polydipsia, such as hyperglycemia, azotemia, or primary polydipsia, were discarded (Table 1). Therefore, an ultrasound and parathyroid scan using sestamibi were performed upon suspicion of a diagnosis of parathyroid adenoma; the results were normal (Figure 1). Subsequently, the calcium/creatinine clearance ratio was calculated; it was 0.0047 , suggestive of FHH (Table 2). Finally, the diagnosis was confirmed by a genetic study using the 
Sanger sequencing of the coding region and intronexon junctions of the CaSR gene, which confirmed that the patient is a heterozygous carrier of the likely pathogenic variant c.493-2A>G;p? in the CaSR gene.

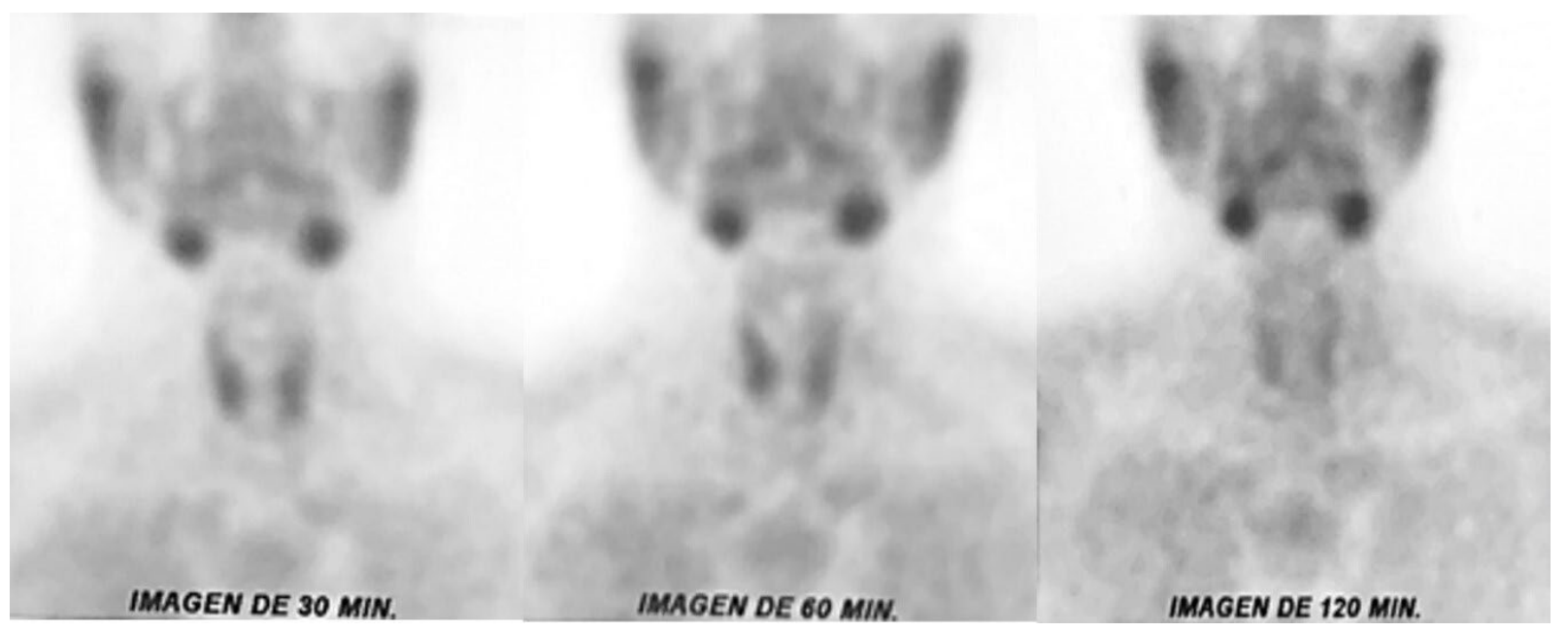

Figure 1. Parathyroid scan 30, 60 and 120 minutes after administration of sestamibi Tc-99m radiotracer. In these images, thyroid gland is observed with the administration of the radiotracer. Nevertheless, there is no abnormal uptake in the parathyroid gland during the time of the study that could suggest a parathyroid adenoma.

Source: prepared by the authors.

Table 1. Laboratory tests run on the patient for the study of polyuria and hypercalcemia

\begin{tabular}{ccc} 
Laboratory test & Result & Reference value \\
\hline Fasting glycemia & $95 \mathrm{mg} / \mathrm{dL}$ & $70-100 \mathrm{mg} / \mathrm{dL}$ \\
\hline HbA1c & $4.9 \%$ & $<6.5 \%$ \\
\hline Serum calcium & $10.7 \mathrm{mg} / \mathrm{dL}$ & $8.4-10.2 \mathrm{mg} / \mathrm{dL}$ \\
\hline $\begin{array}{c}\text { 24-hour urine } \\
\text { calcium }\end{array}$ & $132 \mathrm{mg} / \mathrm{dL}$ & $100-321 \mathrm{mg} / 24 \mathrm{hr}$ \\
\hline Serum creatinine & $0.9 \mathrm{mg} / \mathrm{dL}$ & $0.67-1.17 \mathrm{mg} / \mathrm{dL}$ \\
\hline $\begin{array}{c}\text { 24-hour urine } \\
\text { creatinine }\end{array}$ & $2,303.7 \mathrm{mg} / \mathrm{dL}$ & \\
\hline BUN & $11.6 \mathrm{mg} / \mathrm{dL}$ & $6-20 \mathrm{mg} / \mathrm{dL}$ \\
\hline Urinary osmolarity & $727 \mathrm{mOsm} / \mathrm{lt}$ & \\
\hline Urinary density & 1.020 & $1.000-1.030$ \\
\hline TSH & $0.7 \mathrm{uU} / \mathrm{mL}$ & $0.27-4.2 \mathrm{uU} / \mathrm{ml}$ \\
\hline PTH & $28 \mathrm{pg} / \mathrm{mL}$ & $15-65 \mathrm{pg} / \mathrm{ml}$ \\
\hline 25 OH vitamin D & $36.81 \mathrm{ng} / \mathrm{mL}$ & $>30 \mathrm{ng} / \mathrm{mL}$ \\
\hline Sodium & $142 \mathrm{mEq} / \mathrm{lt}$ & $135-148 \mathrm{mEq} / \mathrm{lt}$ \\
\hline Potassium & $4.06 \mathrm{mmol} / \mathrm{lt}$ & $3.5-5.5 \mathrm{mmol} / \mathrm{lt}$ \\
\hline Chlorine & $101.2 \mathrm{mmol} / \mathrm{lt}$ & $98-107 \mathrm{mmol} / \mathrm{lt}$ \\
\hline Magnesium & $1.97 \mathrm{mg} / \mathrm{dL}$ & $1.5-3.5 \mathrm{mg} / \mathrm{dL}$ \\
\hline Phosphorus & $3.2 \mathrm{mg} / \mathrm{dL}$ & $2.7-4.5 \mathrm{mg} / \mathrm{dL}$ \\
\hline
\end{tabular}

PTH: Parathormone. TSH: Thyroid-stimulating hormone Source: prepared by the authors.
Due to the symptomatic persistent hypercalcemia, treatment with Cinacalcet was started at a dose of $30 \mathrm{mg}$ orally every 12 hours, and migraine medication was prescribed because the patient referred headaches, besides serum calcium level reductions. Under the clinical suspicion of $\mathrm{FHH}$, the patient was referred to the geneticist to perform the disease's respective diagnostic test. Once treatment with Cinacalcet was started, the symptoms of polydipsia and polyuria improved significantly. However, the patient's intense episodes of headache persisted until prescribed the migraine medication with a good response. The patient reported a significant improvement in his quality of life after the diagnosis and treatment were established. However, the patient will require follow-up by the endocrinologist indefinitely.

\section{Discussion}

The CaSR gene is located on chromosome 3q13.3-21, which contains six exons that encode a 1078-amino acid transmembrane glycoprotein, whose intracellular domain is coupled to a heterodimeric G-protein. Its activity is concentrated in the parathyroid gland and the kidney, inhibiting the PTH secretion and favoring calcium reabsorption in the ascending branch of Henle's Loop, respectively. Mutations in this and other genes, such as GNA11 and AP2S1, may be triggered in inherited disorders presenting PTH-independent 
hypercalcemia with relative hypocalciuria. However, the CaSR mutation comprises $65 \%$ of the pathogenic mutations of FHH patients $(1,2)$. Although it is often asymptomatic, on some occasions, it can occur with pancreatitis, chondrocalcinosis, and headaches (7). The latter two were present in the patient; however, he did not report abdominal pain, nausea, vomiting, or other clinical manifestations to suggest acute pancreatitis.

The FHH diagnosis began with a biochemical profile of mild hypercalcemia with levels of unsuppressed PTH $($ PTH $>20-25 \mathrm{pg} / \mathrm{ml})$, compatible with primary hyperparathyroidism. Subsequently, the measurement of the calcium/creatinine clearance ratio (Table 2) was suggested to differentiate between $\mathrm{FHH}$ and primary hyperparathyroidism by glandular autonomy, where an index lower than 0.01 with a sensitivity of $80 \%$ and a specificity of $88 \%$ was interpreted as highly suggestive of FHH (Table 2) (7-10). The patient's parathyroid scan using sestamibi was performed prior to determining the index because sporadic primary hyperparathyroidism is the most frequent cause of hypercalcemia in nonhospitalized patients. Of this frequency, $80 \%$ to $90 \%$ is caused by an overactive parathyroid gland adenoma, where multiglandular hyperplasia or parathyroid carcinoma are highly rare $(3,11,12)$.

Table 2. Interpretation of the calcium/creatinine clearance ratio

$\begin{array}{cccc}\begin{array}{c}\text { Serum } \\ \text { calcium }\end{array} & \begin{array}{c}\text { Serum } \\ \text { creatinine }\end{array} & \begin{array}{c}\mathbf{2 4} \text { hour urine } \\ \text { calcium }\end{array} & \begin{array}{c}\mathbf{2 4} \text { hour } \\ \text { urine } \\ \text { creatinine }\end{array} \\ \begin{array}{c}10.7 \mathrm{mg} / \\ \mathrm{dL}\end{array} & 0.9 \mathrm{mg} / \mathrm{dL} & \begin{array}{c}132.4 \mathrm{mg} / 24 \\ \text { hours }\end{array} & \begin{array}{c}2,303 \mathrm{mg} / 24 \\ \text { hours }\end{array} \\ \begin{array}{cccc}\text { Calcium/ } \\ \text { Creatinine } \\ \text { Clearance } \\ \text { ratio }\end{array} & \begin{array}{c}\text { Serum calcium }\left(\frac{\mathrm{mg}}{\mathrm{dL}}\right) \\ =0.0047\end{array} & \begin{array}{c}\text { Serum creatinine }\left(\frac{\mathrm{mg}}{\mathrm{dL}}\right) \\ 24 \mathrm{hr} \text { r urine creatinine }\end{array} & \begin{array}{c}\text { Meaning: } \\ >0.01: \mathrm{FHH}\end{array} \\ & & \begin{array}{c}\text { unlikely } \\ <0.01: \text { FHH } \\ \text { highly likely }\end{array}\end{array}$

Source: prepared by the authors.

Most cases of FHH do not require any treatment, and the morbidity is often the result of unnecessary surgery. While there are reports of symptoms and morbidity related to hypercalcemia in FHH patients, they are a minority of the cases (6).

Calcimimetic drugs, such as Cinacalcet, are allosteric CaSR agonists. They enhance the effect of extracellular calcium on CaSR in the parathyroid cell, thus decreasing PTH secretion and serum calcium. Cinacalcet's use has been considered when calcium is $1 \mathrm{mg} / \mathrm{dl}$ above the upper limit of the reference value or when the patient has symptoms associated with hypercalcemia. Case series have described a response rate in up to $88 \%$ of patients with symptom control, even without achieving normal calcium levels in some (13). There are also case reports on the treatment with Cinacalcet to prevent recurrent pancreatitis, demonstrating its safety and prevention of new episodes (14).

A publication compiled the reasons for initiating Cinacalcet treatment in a series of FHH patients. Hypercalcemia was the main reason for starting Cinacalcet treatment in six subjects. Primary hyperparathyroidism was the reason in three patients and pancreatitis in two. Other reasons for starting therapy included muscle cramps, bone pain, poor memory, and psychosis in one case. Improvement of symptoms, associated with the normalization of serum calcium levels, was described in most patients, with adequate safety at three years using a dose between $30-90 \mathrm{mg}$. The most common adverse effects were nausea, hypotension, and hypocalcemia. The symptoms improved after the Cinacalcet dose was reduced without interrupting treatment (15). Another series of four reported cases demonstrated adequate symptomatic control of cramps, memory loss, paresthesia, vertigo, and constipation, with improved calcium levels and without adverse events, with doses of 30-60mg of Cinacalcet (16).

\section{Conclusions}

FHH is an infrequent diagnosis that in some cases may be underdiagnosed, leading to unnecessary surgical procedures. Moreover, there is insufficient local data to estimate the prevalence of this disease in our population. Therefore, patients with mild hypercalcemia, unsuppressed parathyroid hormone (above 25pg/ $\mathrm{ml}$ ), a calcium/creatinine clearance ratio below 0.001 , or patients with primary hyperparathyroidism with negative neck imaging should not undergo surgical neck exploration. In these cases, familial hypocalciuric hypercalcemia should be considered a reliable diagnosis. There is also evidence that supports the use of Cinacalcet in cases of symptomatic hypercalcemia.

\section{Conflicts of interest}

The authors declare no conflicts of interest.

\section{Financiation}

No funds were received to write this paper. 


\section{References}

1. Lee JY, Shoback DM. Familial hypocalciuric hypercalcemia and related disorders. Best Pract Res Clin Endocrinol Metab [Internet]. 2018;32(5):609619. doi: https://doi.org/10.1016/j.beem.2018.05.004

2. D'Souza-Li L, Yang B, Canaff L, Bai M, Hanley DA, Bastepe M, et al. Identification and Functional Characterization of Novel Calcium-Sensing Receptor Mutations in Familial Hypocalciuric Hypercalcemia and Autosomal Dominant Hypocalcemia. J Clin Endocrinol Metab [Internet]. 2002;87(3):1309-18. doi: https://doi.org/10.1210/jcem.87.3.8280

3. Builes-Montaño CE. Hiperparatiroidismo primario. Med. Lab [Internet]. 2017;23(1-2):45-4. doi: https:// doi.org/10.36384/01232576.59

4. Dershem R, Gorvin CM, Metpally RPR, Krishnamurthy S, Smelser DT, Hannan FM, et al. Familial Hypocalciuric Hypercalcemia Type 1 and Autosomal-Dominant Hypocalcemia Type 1: Prevalence in a Large Healthcare Population. Am J Hum Genet [Internet]. 2020;106(6):734-47. doi: https://doi.org/10.1016/j.ajhg.2020.04.006

5. Mahajan A, Buse J, Kline G. Parathyroid hormonedependent familial hypercalcemia with low measured PTH levels and a presumptive novel pathogenic mutation in CaSR. Osteoporos Int [Internet]. 2020;31:203-7. doi: https://doi.org/10.1007/s00198019-05170-9

6. Brown EM. Clinical lessons from the calcium-sensing receptor. Nat Rev Endocrinol [Internet]. 2007;3:122133. doi: https://doi.org/10.1038/ncpendmet0388

7. Merino M, Vega B, Guijarro G, Navea $C$, Torán $C$, Civantos S. Familial hypocalciuric hypercalcemia: sometimes it is not what it seems. Rev Osteoporos Metab Miner [Internet]. 2015;7(1):20-22. doi: https:// doi.org/10.4321/S1889-836X2015000100005

8. Renaghan AD, Rosner MH. Hypercalcemia: etiology and management. Nephrol Dial Transplant [Internet]. 2018;33(4):549-551. doi: https://doi.org/10.1093/ndt/ gfy054

9. Silva BC, Cusano NE, Bilezikian JP. Primary hyperparathyroidism. Best Pract Res Clin Endocrinol
Metab [Internet]. 2018;32(5):593-607. doi: https:// doi.org/10.1016/j.beem.2018.09.004

10. Fuleihan GEH, Silverberg SJ. Primary hyperparathyroidism: Diagnosis, differential diagnosis, and evaluation. Post TW, ed. Waltham, MA: UpToDate Inc [Internet]. 2020. Available from: https://www.uptodate.com/contents/primaryhyperparathyroidism-diagnosis-differentialdiagnosis-and-evaluation? search $=$ primary $\% 20$ hyperparathyroidism\&source =search result\&selectedTitle $=1 \sim 119 \&$ usage type $=$ default\&display rank $=1$

11. Pulgar D, Jans J, D’Aguzan N, León A, Goñi I, González G, et al. Hiperparatiroidismo primario: manejo quirúrgico. Rev Chil Cir [Internet]. 2014;66(4):313-319. doi: https://doi.org/10.4067/ S0718-40262014000400004

12. Bilezikian JP. Primary Hyperparathyroidism. J Clin Endocrinol Metab [Internet]. 2018;103(11):39934004. doi: https://doi.org/10.1210/jc.2018-01225

13. Marx SJ. Calcimimetic Use in Familial Hypocalciuric Hypercalcemia-A Perspective in Endocrinology. J Clin Endocrinol Metab [Internet]. 2017;102(11):39333936. doi: https://doi.org/10.1210/jc.2017-01606

14. Scheers I, Sokal E, Limaye N, Denoncin C, Stephenne $\mathrm{X}$, Pirson Y, et al. Cinacalcet sustainedly prevents pancreatitis in a child with a compound heterozygous SPINK1/AP2S1 mutation. Pancreatology [Internet]. 2019;19(6):801-804. doi: https://doi.org/10.1016/j. pan.2019.07.045

15. Mayr B, Schnabel D, Dörr HG, Schöfl C. GENETICS IN ENDOCRINOLOGY: Gain and loss of function mutations of the calcium-sensing receptor and associated proteins: current treatment concepts. Eur J Endocrinol [Internet]. 2016;174(5):R189-R208. doi: https://doi.org/10.1530/EJE-15-1028

16. Rasmussen AQ, Jørgensen NR, Schwarz P. Clinical and biochemical outcomes of cinacalcet treatment of familial hypocalciuric hypercalcemia: a case series. $\mathbf{J}$ Med Case Rep [Internet]. 2011;5:564. doi: https://doi. org/10.1186/1752-1947-5-564 